\title{
Biology of Pearl Millet Ear Head Worm, Helicoverpa armigera under Laboratory Condition
}

\author{
N.N. Chauhan, F.K. Chaudhary, H.N. Patel" and N.M. Kachhadiya \\ College of Agriculture, Junagadh Agricultural University, Junagadh, Gujarat, India \\ *Corresponding author
}

\begin{abstract}
A B S T R A C T
Keywords

Pearl Millet, earhead worm,

Biology,

Helicoverpa

armigera

Article Info

Accepted:

xx December 2017

Available Online:

xx January 2018

Investigations were carried out on biology of ear head worm, Helicoverpa armigera (Hub.) in pearl millet at Sardarkrushinagar Dantiwada Agricultural University, Sardarkrushinagar during the year 2011. External features of all the stages were described and length and width of all the stages were measured and reported. The duration of various stages was studied under laboratory conditions at an average temperature of $17.50 \pm 1.70{ }^{\circ} \mathrm{C}$ and $57.10 \pm 9.42$ per cent relative humidity. The incubation period was 3.80 days and 87.65 per cent eggs hatched. Freshly hatched larva fed on stigma and later instar of the larvae fed on anthers and grown on ear head by preparing protection cover of dry anthers. It also damage ear head covering leaves. The larvae passed through six instars. The total larval, prepupal and pupal period was 19.20, 1.64 and 12.48 days, respectively. Maximum pupation took place in soil between 2 to $8 \mathrm{~cm}$ depths in dry soil. Sex ratio of male: female was 1:1.16 shows preponderance of female population over male. The average preoviposition, oviposition and post-oviposition periods were 3.08, 4.52 and 1.92 days, respectively. The average fecundity was 565 eggs per female, when reared on pearl millet. The average longevity of male and female was $7.56 \pm 1.29$ and $9.52 \pm 1.42$ days whereas total life period was $44.68 \pm 2.23$ and $46.64 \pm 1.41$ days when reared on pearl millet.
\end{abstract}

\section{Introduction}

Pearl millet, Pennisetum glaucum (L.) commonly known as pearl, cat tail, spiked or bulrush millet in English is world's sixth important and widely grown potential cereal food crop. In United States of America, Australia and South Africa, it is primarily grown as forage crop. The pearl millet is an annual tillering diploid $(2 n=14)$ belongs to family Gramineae, sub-family Peniceidae. In our country, it is known by many names in different languages, Bajri in Rajasthani, Gujarati and Marathi, Sajje in Kannada, Kambu in Tamil, Bajra in Hindi, Urdu and Panjabi and Sajjalu in Telugu.

In India, pearl millet is the fourth most important food grain crop after rice, wheat and sorghum. As an arid and semi-arid crop, pearl millet is the component of dry land ecosystem which receives 15 to $175 \mathrm{~cm}$ rainfall per annum. The share of pearl millet in total food grain production of the country is to the tune of 10.7 per cent. It occupies an area of 
8.73 million hectares having 8.89 million tones production. Traditionally, it is used as porridge. Now a days, bakery products like cakes, muffins, cookies and biscuits are enhanced with pearl millet flour. In Gujarat, it occupied an area of 7.03 lakh hectare having 9.61 lakh tones production with $1370 \mathrm{~kg} / \mathrm{ha}$ productivity as kharif grown crop (Anon., 2009) while, in summer it occupied 1.74 lakh hectare having 4261 tones production with $2440 \mathrm{~kg} /$ ha productivity (Anon., 2010).

Pearl millet grains contain protein $(9-15 \%)$, fat $(5 \%)$ and mineral matters $(2-7 \%)$. It is also rich in vitamins $\mathrm{A}$ and $\mathrm{B}$, thiamin and riboflavin contents and imparts substantial energy to the body with easy digestibility. Apart from grain, the fodder and straw at harvest are important secondary products in low resource agriculture for animal feed and fuel. Due to low yield potential as well as fluctuating grain prices plant protection measures are hardly applied. However, potentiality of high yielding hybrid varieties attract heavy incidence of pests. Crop is attacked by a number of insect pests, viz., Ear head worm, Helicoverpa armigera Hubner; Gujarat hairy caterpillar, Amsacta moorei; Army worm, Cirphis unipuncta H.; Stem borer, Chilo zonellus; Blister beetle, Cylindrothorax ruficolis F.; Shoot fly, Atherigona varia socata M.; Surface grasshopper, Chrotogonus brachypterous B. and White grub, Holotrichia consanguinea B. (Patel et al., 1970).

Over last few years a pest known as pearl millet ear head worm, $H$. aremigera Hub. is appearing in the summer sown crop. It is most probable due to the bio-diversity of the pest. Adoption of Bt. cotton varieties in large area of the state, the pest diverted towards the available hosts for its existence. Considerable research work has been done on this international pest on its preferred host, like pulses, oil seeds, fruit and vegetable crops, but very scanty information is available in respect to pearl millet. For developing suitable pest management strategies, it is essential to study the aspect on Biology of pearl millet ear head worm, Helicoverpa armigera under laboratory condition.

\section{Materials and Methods}

The investigation on biology of pearl millet ear head worm, Helicoverpa armigera (Hubner) was carried out during the course of study. The materials used and methodology adopted for this aspect of present investigation is described here under.

A study on biology of $H$. armigera was carried out in the laboratory of Department of Agricultural Entomology, C. P. College of Agriculture, Sardarkrushinagar Dantiwada Agricultural University, Sardarkrushinagar during the year 2011. During the study period the average temperature and relative humidity was $17.50 \pm 1.70{ }^{\circ} \mathrm{C}$ and $57.10 \pm 9.42$ per cent, respectively.

\section{Rearing Techniques}

Initially the larvae of $H$. armigera were collected from the infested field of Pearl millet from the farmers' field. Each larva was kept in clean glass Petri dish $(15 \mathrm{~cm}$ diameter, $1.5 \mathrm{~cm}$ height) in the laboratory. A small piece of freshly emerged ear head of Pearl millet was provided as a food. The full grown larvae were transferred to the plastic jar $(11 \mathrm{~cm}$ length $\times 9 \mathrm{~cm}$ width $\times 15 \mathrm{~cm}$ height) having one third part of the jar filled with moist soil to facilitate the pupation. After pupation the glass jar was kept as such and observed regularly to record the emergence of the adults. The adults emerged were utilized for further study on various aspects of biology. Newly emerged adults were paired and confined in an iron rearing cage. Fresh Pearl millet ear head was provided inside the cage 
for egg laying purpose. The cut end of pearl millet ear head was kept in conical flask (250 $\mathrm{ml}$ ) filled with water and fixed with a cotton plug to keep the ear head fresh and turgid for long period. A piece of $5 \times 5 \mathrm{~cm}$ sized sponge submerged in 5 per cent honey solution was also provided for the food to the adults. The pearl millet ear head and piece of sponge were replaced every morning. The eggs laid on pearl millet ear head were utilize for further study.

\section{Egg}

The freshly laid eggs on ear head were located by close observation. The eggs were examined under microscope to study their colour and shape. For measuring length and width, freshly laid eggs were transferred with fine camel hair brush on the glass slide and measured under microscope with the help of ocular micrometer after calibrating it with stage micrometer. To study the incubation period and hatching percentage of eggs, freshly laid eggs were transferred in petri dish and observed under microscope daily in the morning and evening till they hatched. The eggs were considered as hatched when tiny larva came out from the eggs. Incubation period was then calculated based on date of oviposition and hatching. Hatching percentage was also calculated from the number of eggs hatched out of the total number of eggs kept under observation.

\section{Larva}

With a view to determine the number and duration of different larval instars and total larval period, the newly emerged larvae (first instar) were transferred individually in petri dishes (15 cm diameter ; $1.5 \mathrm{~cm}$ height) with the help of fine camel hair brush. Tender ear head piece was provided as the food. The food in each Petri dish was changed daily in the morning. To determine the number of larval instars, the size of individual larva observed daily till the moulting. The moulting was confirmed by presence of casted off head capsule and increased size of larva of subsequent instars. The larvae in each instar was closely observed for their colour, shape and size. Observations on number of instars, duration of each instar and total larval period were also recorded separately. Length and width of first two instars were observed under microscope with the help of occular micrometer after calibrating it with stage micrometer. While, the length and width for third to sixth instar were measured by using graph paper. The total larval duration was calculated from the date of hatching of egg to the date of formation of prepupa.

\section{Nature of damage}

The infested pearl millet ear heads were observed critically to study the nature of damage done by the larvae. Prepupa; Full grown sixth instar larva stopped feeding, contracted in size and became sluggish was considered to be in the prepupal stage. The prepupal period was recorded individually from inactive stage to the formation of pupa. Observations on colour, shape and size and length and width were measured. Pupa; Pupa was observed critically for their colour, shape, size and pupal duration was also calculated. The length and width was also measured by using graph paper. The time interval between formation of pupa and emergence of adult was considered as pupal duration.

\section{Adult; Colour, appearance and size}

The adults were killed in insect killing jar, pinned, dried and preserved with wing expansion. Such preserved adults were observed under microscope to study their colour, shape, appearance and sex differences. The length and width of the adults with expanded wings were also measured and 
recorded. Sex ratio: To study the sex ratio, laboratory reared adults were observed critically (male and female) on the basis of morphological characters and separated sex wise. Number of males and females were counted and on the basis of these data, sex ratio was worked out.

\section{Pre-oviposition, oviposition and post - oviposition periods}

To study the pre-oviposition, oviposition and post-oviposition periods of adult female, the freshly emerged adult male and female were paired and confined in iron rearing cage separately for egg laying. Piece of sponge submerged with five per cent honey solution was provided for their food. Freshly emerged ear head of pearl millet were provided for egg laying. The piece of sponge submerged with honey solution and the ear head were replaced every day. The eggs laid by each female on ear head, rearing cage wall, Petri dish and muslin cloth were collected daily with the help of fine camel hair brush and total number of eggs laid by each female was recorded separately. The date of emergence of adult females, date of beginning of oviposition and cessation of oviposition were recorded. Period between the emergence of female from the pupa and commencement of egg laying was considered as the pre-oviposition period.

Period between commencement of egg laying and cessation of egg laying was noted as oviposition period, while the period between cessation of egg laying to the death of female was considered as post-oviposition period.

\section{Fecundity}

The number of eggs laid by each female was recorded daily till the cessation of egg laying and average fecundity of each female was worked out separately. Longevity
Longevity of male and female was calculated separately from the date of emergence to the date of death of the respective adults.

\section{Total life period}

The period between egg laying and death of adults was considered as total life period.

\section{Results and Discussion}

Studies on biology of H. armigera was carried out on pearl millet at an average room temperature of $17.50 \pm 1.70{ }^{\circ} \mathrm{C}$ and relative humidity $57.10 \pm 9.42$ per cent in the laboratory of department of Agricultural Entomology during 2011. The results on size, shape, appearance and duration of various stages are presented here under.

\section{Egg}

\section{Colour, shape and size}

Freshly laid eggs on pearl millet were shiny greenish, yellowish or waxy white in colour with dome shaped and flat base. The shell has minute ribs, which radiate downward from the top to the base. Just before hatching, the colour of the egg turned to dark brown. The eggs were laid singly, on the ear head of the pearl millet. Observation on measurement of eggs revealed that the length of eggs varied from 0.34 to 0.53 (Av. $0.48 \pm 0.04$ ) mm however, the breadth varied from 0.30 to 0.51 (Av. $0.45 \pm 0.05$ ) $\mathrm{mm}$ (Table 1). The present findings are in accordance with Trapsia et al., (2007a). They reported that the colour of freshly laid egg of pearl millet ear head worm was shiny greenish, yellowish or waxy white. Egg was shiny and dome shaped with a flat base. The length and width of egg was 0.48 to 0.53 (Av. $0.51 \pm 0.02$ ) $\mathrm{mm}$ and 0.48 to 0.51 $(0.48 \pm 0.01) \mathrm{mm}$, respectively.

Incubation period 
The incubation period varied from 3 to 5 days with an average of $3.80 \pm 0.82$ days at an average temperature $17.50 \pm 1.70{ }^{\circ} \mathrm{C}$ and relative humidity $57.10 \pm 9.42$ per cent (Table $2)$. The present findings are in accordance with that of Patel (1976). He reported the incubation period of 4 days for the eggs of $H$. armigera. Kashyap and Dhindhsa (1990) reported that the egg stage lasted for 2 to 7 days at 17.50 to $27.50{ }^{\circ} \mathrm{C}$ temperature during October-November and 5 to 9 days at 13.20 to $18.50{ }^{\circ} \mathrm{C}$ temperature in December. Akashe et al., (1997) reported that the eggs incubated in 2 to 4 days. Trapsia et al., (2007a) at Junagadh reported incubation period to vary from 3 to 5 (Av. $3.72 \pm 0.79$ ) days on pearl millet. The average incubation period was 4.04 days, when larvae were reared on cabbage under laboratory conditions (Thakor et al., 2009).

\section{Hatching percentage}

It can be seen from Table 6 that, hatching percentage of eggs laid on pearl millet was 87.65 at an average temperature $18.5 \pm 1.34$ ${ }^{\circ} \mathrm{C}$ and relative humidity of 52.20 per cent. Almost nearest egg hatching percentage $(90.89 \pm 5.23)$ has been reported by Bhatt and Patel (2001) on chickpea.

\section{Larva}

\section{First instar}

During hatching, the young larvae made a hole on the side of its head in the egg shell and slowly emerged out and fed most of the shell material. Freshly emerged larvae were semitranslucent, yellowish white in colour with yellowish orange longitudinal lines on dorsal surface of body. The head, thoracic and anal shields and legs were brown in colour. The results (Table 1) on measurement of first instar larva revealed that the length varied from 1.10 to 3.00 (Av. $1.95 \pm 0.56$ ) $\mathrm{mm}$, while the width varied from 0.15 to 0.42 (Av. $0.29 \pm$ $0.08) \mathrm{mm}$. The duration of first instar larvae varied from 2 to 3 (Av. $2.48 \pm 0.51$ ) days (Table 5). The present findings are in close agreement with the findings of Trapsia et al., (2007a). They reported that the freshly emerged first instar larvae were yellowish with a black head. The length and width ranged between 1 and 3 (Av. $2.20 \pm 0.65$ ) $\mathrm{mm}$ and 0.2 and 0.4 (Av. $0.31 \pm 0.08$ ) mm, respectively. The duration was 2 to 3 (Av. $2.60 \pm 0.50)$ days, when reared on pearl millet. Thakor et al., (2009) recorded that an average development period of first instar larvae was 2.16 days on at Sardarkrushinagar (Gujarat).

\section{Second instar}

The colour of second instar larva was reddish brown with dark brown hairs and pigments. The results on measurement of second instar larvae revealed that the length varied from 5.00 to 5.80 (Av. $5.36 \pm 0.18$ ) mm, while the width varied from 0.64 to 0.80 (Av. $0.73 \pm$ 0.04) $\mathrm{mm}$ (Table 4). The larval duration ranged between 2 to 4 (Av. $2.76 \pm 0.72$ ) days (Table 5). The above findings on colour, size and duration of second instar larvae of $H$. armigera are more or less similar to findings of Trapsia et al., (2007a). They reported that second instar larva was reddish brown in colour and the length and width measured 5.10 to 5.60 (Av. $5.34 \pm 0.15) \mathrm{mm}$ and 0.68 to 0.75 $(0.72 \pm 0.03) \mathrm{mm}$, respectively. The larval duration was 2 to 4 (Av. $3.12 \pm 0.78$ ) days. Thakor et al., (2009) reported that the duration of second instar larvae of $H$. armigera was 2.80 days when reared on cabbage.

\section{Third instar}

The colour of the third instar larvae turned pale brown. The skin took granular appearance and body surface was covered with stiff hairs. The dorsal side consisted of a pale white strip. On lateral parts of the body 
broad light bands were seen in which the spiracles were clearly visible. The ventral surface of the larvae was uniform and pale in colour.

The length of third instar larvae varied from 8.00 to 12.10 (Av. $10.89 \pm 0.92) \mathrm{mm}$, while the width varied from 1.20 to 1.50 (Av. $1.33 \pm$ $0.10) \mathrm{mm}$ (Table 4). The duration of third instar larvae ranged between 2 to 5 (Av. 3.08 \pm 1.08 ) days (Table 2 ).

The above findings on size, shape and appearance of third instar larvae of ear head worm are in accordance with those reported by Trapsia et al., (2007a) at Junagadh (Gujarat).

\section{Fourth instar}

The colour of the fourth instar larvae was greenish yellow. The body surface was covered by close set of minute tubercles. The narrow dark bands with varying colour appeared on the middle of the back. They may be broader and appeared as one stripe with a narrow line in the middle and the middle line may be broken and appeared as a series of light coloured dashes.

The results (Table 4) on measurement of fourth instar larva revealed that the length varied from 16.00 to 19.20 (Av. $17.02 \pm 0.96$ ) $\mathrm{mm}$, while the width varied from 2.00 to 2.90 (Av. $2.39 \pm 0.34$ ) $\mathrm{mm}$. The duration of larvae ranged between 2 to 5 (Av. $2.92 \pm 0.90$ ) days (Table 2).

Trapsia et al., (2007a) revealed that the length and width of fourth instar larvae varied from 16.00 to 18.60 (Av. $17.43 \pm 0.76$ ) $\mathrm{mm}$ and 2.00 to 2.50 (Av. $2.18 \pm 0.14$ ) $\mathrm{mm}$, respectively. The larval duration was 2 to 4 (Av. $3.20 \pm 0.76$ ) days when the larvae reared on pearl millet. Thus, the results on size, appearance and duration of fourth instar larvae of $H$. armigera are more or less in class confirmity with above reports.

\section{Fifth instar}

The body colour of the fifth instar larva was just similar to fourth instar larvae. The head was reddish yellow or light brown in colour.

The results (Table 1) on measurement of fifth instar larva revealed that the length varied from 23.00 to 23.60 (Av. $23.29 \pm 0.18$ ) $\mathrm{mm}$, while the width varied from 2.70 to 3.20 (Av. $2.90 \pm 0.20) \mathrm{mm}$. The larval duration varied from 3 to 6 (Av. $3.72 \pm 0.94$ ) days (Table 2).

The present results on size, appearance and duration of fifth instar larva of $H$. armigera was in close agreement with the report made by Trapsia et al., (2007a). They reported that the length and width varied from 23 to 25 (Av.24.39 \pm 0.17 ) $\mathrm{mm}$ and 2.90 to 3.20 (Av. $3.05 \pm 0.12) \mathrm{mm}$, respectively, when reared on pearl millet. The larval duration of fifth instar was 2 to 4 (Ave. $3.52 \pm 0.59$ ) days.

\section{Sixth instar}

A full-grown larva was greenish with dark broken grey lines along the side of the body. These lines vary in width and in intensity of colour.

Their colour was variable like green, straw coloured, yellow and reddish brown or black. The head was greenish yellow. On each segment there were number of inconspicuous tubercles from which a short hair arised.

The length of full grown larvae varied from 24.30 to 25.00 (Av. $24.67 \pm 0.26$ ) $\mathrm{mm}$, while width varied from 3.00 to 3.15 (Av. $3.07 \pm$ 0.05) $\mathrm{mm}$ (Table 1). The duration of sixth instar larvae varied from 3 to 6 (Av. $4.24 \pm$ 0.93) days (Table 2). 
Table.1 Measurement of different stages of $H$. armigera

\begin{tabular}{|l|c|c|c|c|c|c|}
\hline \multicolumn{1}{|c|}{ Stage } & \multicolumn{3}{|c|}{ Length $(\mathbf{m m})$} & \multicolumn{3}{c|}{ Breadth $(\mathbf{m m})$} \\
\hline & Min. & Max. & Av. \pm S.D. & Min. & Max. & Av. \pm S.D. \\
\hline Egg & 0.34 & 0.53 & $0.48 \pm 0.04$ & 0.30 & 0.51 & $0.45 \pm 0.05$ \\
\hline Larvae & & & & & & \\
\hline I Instar & 1.10 & 3.00 & $1.95 \pm 0.56$ & 0.15 & 0.42 & $0.29 \pm 0.08$ \\
\hline II Instar & 5.00 & 5.80 & $5.36 \pm 0.18$ & 0.64 & 0.80 & $0.73 \pm 0.04$ \\
\hline III Instar & 8.00 & 12.10 & $10.89 \pm 0.92$ & 1.20 & 1.50 & $1.33 \pm 0.10$ \\
\hline IV Instar & 16.00 & 19.20 & $17.02 \pm 0.96$ & 2.00 & 2.90 & $2.39 \pm 0.34$ \\
\hline V Instar & 23.00 & 23.60 & $23.29 \pm 0.18$ & 2.70 & 3.20 & $2.90 \pm 0.20$ \\
\hline VI Instar & 24.30 & 25.00 & $24.67 \pm 0.26$ & 3.00 & 3.15 & $3.07 \pm 0.05$ \\
\hline Pupa & & & & & & \\
\hline Prepupa & 19.00 & 21.20 & $19.98 \pm 0.63$ & 3.60 & 3.90 & $3.74 \pm 0.09$ \\
\hline Pupa & 18.00 & 19.10 & $18.61 \pm 0.37$ & 4.30 & 4.60 & $4.48 \pm 0.10$ \\
\hline Adult & & & & & & \\
\hline Male & 18.00 & 19.50 & $19.20 \pm 0.42$ & 37.00 & 39.00 & $38.73 \pm 0.50$ \\
\hline Female & 21.50 & 23.50 & $22.62 \pm 0.66$ & 44.50 & 46.00 & $45.36 \pm 0.59$ \\
\hline
\end{tabular}

Table.2 Details of life period of $H$. armigera

\begin{tabular}{|c|c|c|}
\hline \multirow[t]{2}{*}{ Sr. No. } & \multirow[t]{2}{*}{ Stage } & Duration (Days) \\
\hline & & Range (Average) \\
\hline 1 & Incubation period & $3-5(3.8 \pm 0.82)$ \\
\hline \multirow[t]{8}{*}{2.} & Larva & \\
\hline & I Instar & $2-3(2.48 \pm 0.51)$ \\
\hline & II Instar & $2-4(2.76 \pm 0.72)$ \\
\hline & III Instar & $2-5(3.08 \pm 1.08)$ \\
\hline & IV Instar & $2-5(2.92 \pm 0.90)$ \\
\hline & V Instar & $3-6(3.72 \pm 0.94)$ \\
\hline & VI Instar & $3-6(4.24 \pm 0.93)$ \\
\hline & Total larval period & $17-22(19.20 \pm 1.29)$ \\
\hline 3. & Pre-pupal & $1-2(1.64 \pm 0.49)$ \\
\hline 4. & Pupal & $10-15(12.48 \pm 1.58)$ \\
\hline \multirow[t]{3}{*}{5.} & Adult & \\
\hline & Male & $5-9(7.56 \pm 1.29)$ \\
\hline & Female & $8-13(9.52 \pm 1.42)$ \\
\hline \multirow[t]{3}{*}{6.} & Total life period & \\
\hline & Male & $41-48(44.68 \pm 2.23)$ \\
\hline & Female & $43-49(46.64 \pm 1.41)$ \\
\hline 7. & Temperature $\left({ }^{\mathbf{C}} \mathrm{C}\right)$ & $17.50 \pm 1.70$ \\
\hline 8. & Relative humidity (\%) & $57.10 \pm 9.42$ \\
\hline 9. & Study period & $13-12-2010$ to $30-1-2011$ \\
\hline
\end{tabular}


Table.3 Hatching percentage of eggs of $H$. armigera

\begin{tabular}{|c|c|c|c|c|c|}
\hline $\begin{array}{l}\text { Period of } \\
\text { study }\end{array}$ & $\begin{array}{c}\text { Temperature } \\
\left({ }^{\circ} \mathrm{C}\right)\end{array}$ & $\begin{array}{l}\text { R. H. } \\
(\%)\end{array}$ & No. of eggs observed & $\begin{array}{l}\text { No. of eggs } \\
\text { hatched }\end{array}$ & $\begin{array}{c}\text { Hatching } \\
\text { percentage }\end{array}$ \\
\hline \multirow{10}{*}{$\begin{array}{c}19 / 01 / 2011 \\
\text { to } \\
29 / 01 / 2011\end{array}$} & \multirow{10}{*}{$\begin{array}{c}15.7-20.5 \\
(18.5 \pm 1.34)\end{array}$} & \multirow{10}{*}{52.2} & 55 & 49 & 89.09 \\
\hline & & & 90 & 78 & 86.66 \\
\hline & & & 36 & 32 & 88.88 \\
\hline & & & 87 & 71 & 81.60 \\
\hline & & & 62 & 57 & 91.93 \\
\hline & & & 72 & 65 & 90.27 \\
\hline & & & 85 & 71 & 83.52 \\
\hline & & & 61 & 57 & 93.44 \\
\hline & & & 85 & 71 & 83.52 \\
\hline & & & 80 & 74 & 92.50 \\
\hline \multicolumn{3}{|c|}{ Total } & 713 & 625 & 87.65 \\
\hline
\end{tabular}

Table.4 Depth of pupation by $H$. armigera

\begin{tabular}{|c|c|c|}
\hline Sr. No. & Depth $(\mathbf{c m})$ & Number of larvae pupated at different depth in soil \\
\hline 1. & $0-1$ & $1(4.00)^{*}$ \\
\hline 2. & $1-2$ & $2(8.00)$ \\
\hline 3. & $2-3$ & $9(36.00)$ \\
\hline 4. & $3-4$ & $8(32.00)$ \\
\hline 5. & $4-5$ & $3(12.00)$ \\
\hline 6. & $5-6$ & $0(0.00)$ \\
\hline 7. & $6-7$ & $1(4.00)$ \\
\hline 8. & $7-8$ & $1(4.00)$ \\
\hline 9. & $8-9$ & $0(0.00)$ \\
\hline 10. & $9-10$ & $0(0.00)$ \\
\hline
\end{tabular}

* Figure in the parenthesis are per cent values

Table.5 Sex-ratio of $H$. armigera reared on pearl millet

\begin{tabular}{|c|c|c|c|c|c|}
\hline \multirow[t]{2}{*}{ Sr. No. } & \multirow[t]{2}{*}{ Date of emergence } & \multirow[t]{2}{*}{ Total adults emerged } & \multicolumn{2}{|c|}{ Adult emerged } & \multirow{2}{*}{$\begin{array}{c}\text { Sex ratio } \\
\text { Male: Female }\end{array}$} \\
\hline & & & Male & Female & \\
\hline 1 & $17 / 01 / 2011$ & 10 & 4 & 6 & $1: 1.50$ \\
\hline 2 & $18 / 01 / 2011$ & 7 & 3 & 4 & $1: 1.33$ \\
\hline 3 & $19 / 01 / 2011$ & 14 & 6 & 8 & $1: 1.33$ \\
\hline 4 & $20 / 01 / 2011$ & 10 & 5 & 5 & $1: 1.00$ \\
\hline 5 & $21 / 01 / 2011$ & 12 & 5 & 7 & $1: 1.40$ \\
\hline 6 & $22 / 01 / 2011$ & 9 & 4 & 5 & $1: 1.25$ \\
\hline 7 & $23 / 01 / 2011$ & 13 & 7 & 6 & $1: 0.85$ \\
\hline 8 & $24 / 01 / 2011$ & 13 & 6 & 7 & $1: 1.16$ \\
\hline 9 & $25 / 01 / 2011$ & 10 & 4 & 6 & $1: 1.50$ \\
\hline 10 & $26 / 01 / 2011$ & 12 & 7 & 5 & $1: 0.71$ \\
\hline & Total & 110 & 51 & 59 & 1:1.16 \\
\hline
\end{tabular}


Table.6 Pre-oviposition, oviposition, Post-oviposition period and fecundity of $H$. armigera

\begin{tabular}{|c|c|c|c|}
\hline Pre-oviposition & $\begin{array}{c}\text { Duration } \\
\text { Oviposition }\end{array}$ & Post-oviposition & $\begin{array}{c}\text { Number of eggs } \\
\text { laid/female }\end{array}$ \\
\hline Range (Av. \pm S.D.) & & & $360-950$ \\
\hline $2-5$ & $3-7$ & $1-3$ & $(565.00 \pm 196.39)$ \\
\hline
\end{tabular}

The present findings on size, appearance and duration of sixth instar larvae are more or less in accordance with the reports of Trapsia et al., (2007a). They reported that the length and width measured from 24.3 to 24.8 (Av. 24.39 \pm 0.17 ) $\mathrm{mm}$ and 3.04 to 3.11 (Av. $3.09 \pm 0.03$ ) $\mathrm{mm}$ respectively. The larval duration was 3 to 5 (Av. $3.80 \pm 0.76$ ) days on pearl millet. According to Thakor et al., (2009) the larval duration of sixth instar varied from 5 to 7 (Av. $6.30 \pm 0.58$ ) days on cabbage at Sardarkrushinnagar.

\section{Total larval period}

The results obtained from the above investigations revealed that the total larval period varied from 17 to 22 days with an average of $19.20 \pm 1.29$ days at an average $17.50{ }^{\circ} \mathrm{C}$ temperature and $57.10 \pm 9.42$ per cent relative humidity.

The present results on total larval duration are more or less in confirmation with those reported by Doss (1979). In cotton crop, Patel (1981); sorghum, Bhagat \& Bhalani (1994) on different pulses and Patel and Khoshiya (1997) on pearl millet. Trapsia et al., (2007a) reported that the average larval period of $H$. armigera was of $19.20 \pm 1.61$ days when reared on pearl millet. It is in close confirmity with above findings.

\section{Nature of Damage}

The nature of damage due to feeding of ear head worm, $H$. armigera on pearl millet was studied under field condition. The larvae of $H$. armigera caused damage to pearl millet crop during the ear head stage feeding on ear head covering leaves. Freshly hatched larvae fed on stigma which ultimately led to poor grain setting. Later on it fed on anthers and grown on ear head by preparing protection cover of dry anthers and remained unnoticed during this period. Larvae could be detected only when such protective covering of dried anthers was removed by hands. Larvae continued to feed on milky grain and completed larval period before the grain matured and became hard. The present observation on nature of damage of $H$. armigera on pearl millet ear head are in close conformity with those reported by Trapsia et al., (2007a) on pearl millet at Junagadh. Murthy and Mote (1994) also reported same pattern of damage by $H$. armigera on sorghum ear head.

\section{Pre-pupa: Colour, shape, size and duration}

The sixth instar full grown larvae became sluggish, ceased feeding, contracted anterior posterior in size assuming pre-pupal stage. It is clear from (Table 1) that the length and width of pre pupa varied from 19.00 to 21.20 (Av. $19.98 \pm 0.63$ ) $\mathrm{mm}$ and 3.60 to 3.90 (Av. $3.74 \pm 0.09) \mathrm{mm}$, respectively. The prepupal period varied from 1 to 2 (Av. $1.64 \pm 0.49$ ) days (Table 2). The present observation on prepupal stage are in close agreement with the report made by Patel (1976), Patel (1981) and Bapodra (1988), when larvae reared on sunflower, sorghum and chickpea respectively. More or less similar observations were reported by Trapsia et al., 
(2007a) for larva of $H$. armgiera reared on pearl millet at Junagadh (Gujarat).

\section{Pupa: Colour, shape, size and duration}

The Freshly formed pupa was soft and pale brown or greenish in colour and smooth and shining. Within few hours it turned to dark brown colour. The length and width of pupal stage varied from 18.00 to 19.10 (Av. $18.61 \pm$ 0.37 ) $\mathrm{mm}$ and 4.30 to 4.60 (Av. $4.48 \pm 0.10$ ) $\mathrm{mm}$, respectively (Table 1 ). The pupal duration varied from 10 to 15 (Av. $12.48 \pm 1.58$ ) days (Table 2). The present results are in close agreement with the findings of Trapsia et al., (2007a) on pearl millet. They reported that the newly formed pupa was soft and pale brown or greenish in colour and shining. Within few hours it turned in dark brown colour. The length and width varied from 18.00 to 19.10 (18.44 \pm $0.41) \mathrm{mm}$ and 4.49 to 4.55 (Av. $4.53 \pm 0.02$ ) $\mathrm{mm}$, respectively and took 10 to 12 (Av. 10.40 $\pm 0.65)$ days for pupal development, when reared on pearl millet.

\section{Site and depth of pupation}

In laboratory, usually pupation of $H$. armigera took place in soil at varying depth in soil. The results presented in Table 6 indicated that the larva of ear head worm pupated up to $8 \mathrm{~cm}$ depth in soil. The maximum pupation found between 2 and $4 \mathrm{~cm}$ depth. None of the larva preferred to pupate below $8 \mathrm{~cm}$ depth. The present findings are very close to the reports of Trapsia et al., (2007a). They reported the depth of pupation varied from 2.00 to $8.60 \mathrm{~cm}$ in dry loose soil.

\section{Adult: Colour, appearance and size}

The adults of $H$. armigera were extremely variable in colour and markings. In general the colour of the adult varied from olive green to brown with a dark brown circular spot half way between the base and apex of the forewings and a smaller spot near the base. The hind wings were white with some dark spots and have strongly marked veins and a dark margin with two lighter spots on it. The forewing of the freshly emerged male moth was deep olive-buff or olive green with dark brown spot, while it was reddish brown with blackish brown spot in case of female adult. The shape of abdomen of female moth was broad and it was pointed in case of male moth. The length of the adult male varied from 18.00 to 19.50 (Av. $19.20 \pm 0.42$ ) $\mathrm{mm}$ and breadth varied from 37 to 39 (Av. $38.73 \pm 0.50) \mathrm{mm}$, while the length of adult female ranged between 21.50 to 23.50 (Av. $22.62 \pm 0.66) \mathrm{mm}$ and breadth varied from 44.50 to 46.00 (Av. $45.36 \pm 0.59$ ) $\mathrm{mm}$ (Table $1)$. The present results are in close agreement with the findings of Trapsia et al., (2007a). They reported that the colour of adults varies from olive green to brown with a dark brown circular spot half way between the base and apex of the forewing and a smaller spot near the base. The length and width of male moth varied from 18.00 to 19.50 (Av. $19.75 \pm 0.61$ ) $\mathrm{mm}$ and 37 to 39 (Av. $38.00 \pm 0.82$ ) $\mathrm{mm}$, respectively. Whereas that for the female moth varied from 21.50 to 23.30 (Av. $45.13 \pm 0.57$ ) $\mathrm{mm}$, respectively when reared on pearl millet.

\section{Sex ratio}

During the present study, adults of $H$. armigera were obtained from the mass culture reared on pearl millet and maintained in the laboratory. The adults emerged were critically examined and sorted out in to male and female by observing morphological characters. It can be seen from the results presented in Table 6 that out of 110 adults emerged 51 were males, while 59 were females, indicating preponderance of female population over male. Thus, the sex ratio of male: female was found to be 1:1.16 under laboratory condition. The sex ratio of male: female of $H$. armigera has been reported as 1:1.30 (Patel, 1976), 1:1.16 (Trapsia et al., 2007a) and 1:0.61 (Thakor et al., 2009). The variation in sex ratio might be due to differences in host plant used and weather conditions prevailing at different locations. 
Pre-oviposition, oviposition and postoviposition period

The pre-oviposition, oviposition and postoviposition period of mated female varied from 2 to 5 (Av. $3.08 \pm 0.91$ ), 3 to 7 (Av. $4.52 \pm$ 1.01 ) and 1 to 3 (Av. $1.92 \pm 0.81$ ) days, respectively when adults obtained from larvae reared on pearl millet (Table 6). The preoviposition, oviposition and post-oviposition as recorded on sunflower (Patel, 1981), pigeon pea (Bhatt and Patel, 2001) and cabbage (Thakur and Patel, 2008) are in accordance with the findings of present study. The present findings are in close conformity with the finding of Trapsia et al., (2007a) at Junagadh (Gujarat). They reported $2.8 \pm 0.76,4.64 \pm 1.08$ and 2.08 \pm 0.76 days as pre-oviposition, oviposition and post-oviposition period, respectively when the adult obtained from the larvae reared on pearl millet.

\section{Fecundity}

The egg laying capacity of the female of $H$. armigera varied from 360 to 956 (Av. $565 \pm$ 196.39) eggs in pearl millet (Table 6). Contrary to this very high fecundity (552 to 2052 eggs/female) of $H$. armigera was reported by Patel (1976), Chaudhary and Sharma (1981), Bapodra (1988), Varma and Kuldeep Singh (1992), Xia et al., (1997) and Bhatt and Patel (2001) on different hosts.

Trapsia et al., (2007a) at Junagadh (Gujarat) reported very close observations on the fecundity of $H$. armigera when reared on pearl millet. The variation in fecundity reported by various workers may be due to different host and weather conditions of the location.

\section{Adult longevity}

The results on longevity of male and female of H. armigera are presented in Table 3 . It can be seen that the longevity of male and female was 5 to 9 (Av. $7.44 \pm 1.29)$ and 8 to $13(9.52 \pm$ 1.42) days, respectively. Thus, adult longevity of female was longer than that of male. In past,
Patel (1976), Sison and Shanower (1974), Bhatt and Patel (2001) and Nanda and Guajrati (2001) also observed more or less similar longevity of $H$. armigera adults on different hosts. However, average longevity of male as $7.68 \pm 1.14$ \& female as $9.52 \pm 0.82$ days as reported by Trapsia et al., (2007a) are in close conformity with finding of present investigation.

\section{Total life period}

From the results presented in Table 3 , it is evident that the total life period from egg to death of adults ranged between 41 and 48 (Av. 44.68 \pm 2.23 ) days in male and 43 to 49 (Av. $46.64 \pm 1.41)$ days in female.

Thus, female had a longer total life period than male. In past Patel and Talati (1987) reported shorter life span of male (8.26 days) and female (13 days) on sunflower. While, the average life period of 47.40 for male and 50.80 days for female have been reported by Thakor et al., (2009).

However, total life span for male $(43.00 \pm 1.71$ days) and female (44.80 \pm 1.84 days) reported by Trapsia et al., (2007a) on pearl millet are in close conformity with the present findings. The variation in total life period may be attributed to different sources of food and prevailing weather condition at different locations during rearing.

\section{References}

Akashe, V. B.; Mehtre, S. P.; Koli, B, D. and Veer, D. M. 1997. Biology of $H$. armigera on safflower. PKV Research Journal., 21 (2): 230-231.

Anonymous. 2009. Area, Production and Yield of pearl millet during 2009 in respect of major Pearl millet Producing States along with coverage under Irrigation. Directorate of economics and statistics, department of agriculture and cooperation, ministry of agriculture, government of India.

Anonymous. 2010. Area, production and yield of pearl millet during 2010 in Gujarat. Director of Agriculture, Gujarat state. 
Bapodara, J. G. 1988. Biometrical analysis, biology, population dynamics and chemical control of $H$. armigera under Junagadh condition. Ph. D. Thesis Submitted to Gujarat Agricultural University, Sardarkrushinagar.

Bhagat, S. R. and Bhalani, P. A. 1994. Effect of five leguminous host plants on the growth index of gram pod borer, $H$. armigera (Hubner), Gujarat Agricultural University Research Journal., 20 (1): 183-184.

Bhatt. N. J. and Patel, R. K. 2001. Biology of chickpea pod borer, $H$. armigera. Indian J. Ent., 63 (3): 255-259.

Chaudhary, T. P. and Sharma, S. K. 1981. Biology of gram pod borer, $H$. armigera in the Haryana state, Bul Ent., 22 (1/2): 101-112.

Doss, S. A. 1979. Effect of host plants on some biological aspects of the boll worm $H$. armigera. Zeitschrift- Fur-PflanzenkraNkheiten- und-Pflanzenschutz., 86 (314): 143-147.

Kashayap, N. P. and Dhindsa, S. S. 1990. Biology and bionomics of gram pod borer, $H$. armigera on pigeon pea, Indian J. Agric. Science., 60 (2): 157-158.

Murthy, D.K.; Mote, U.N. 1994. Studies on sorghum grain losses due to earhead caterpillar, Heliothis armigera (Hubner). Indian Journal of Entomology., 56 (3): 220-227.

Nanda, N. P. and Gujarati, J. P. 2001. Bionomics of pigeon pea pod borer, $H$. armigera (Hubner) on pigeon pea, Indian J. Agric. Science., 60 (2): 157-158.

Patel, C. C. and Koshiya, D. J. 1997. Life table and innate capacity of increase of $H$. armigera on pearl millet. Indian J. Ent., 59 (4): 389-395.

Patel, Z. P. 1981. Bionomics and control of ear head worms attacking sorghum in South Gujarat. M.Sc. (Agri.) Thesis Submitted to Gujarat Agricultural University, Sardarkrushinagar.

Patel. A. J. 1976. Biology and control of sunflower head borer, $H$. armigera. M.Sc. (Agri.) Thesis Submitted to Gujarat Agricultural University, Sardar krushinagar.

Sison, M. L. J. and Shanover, J. G. 1994. Development and survival of $H$. armigera on short duration pigeon pea J. Econ. Entomol., 32: 1749-1753.

Thakor, S. B.; Patel, I. S. and Jakhar, B. L. 2009. Biology of Helicoverpa armigera (Hub.) on Cabbage, Brassica oleracea var. capitata L. Pestology., 33 (11): 3035.

Trapsia, H. D.; Bharodia R. K., and Kavathia' Y. A. 2007a. Biology of bajra ear head worm, Helicoverpa armigera (Hubner) Int. J. of Bioscience Reporter 5 (1): 205208.

Varma, H. and Kuldeep Singh 1992. Studies on the biology of $H$. armigera on tomato and cauliflower. Thesis Abstract., 18 (4): 273274.

Xia Jingyuan; Mayan and Wang Chan, Yi. 1997. Effect of different host plants on the development and reproduction of the cotton boll worm. Acta Phytophylacica Sinica., 29 (4): 375-376

\section{How to cite this article:}

Chauhan, N.N., F.K. Chaudhary, H.N. Patel and Kachhadiya, N.M. 2018. Biology of Pearl Millet Ear Head Worm, Helicoverpa armigera under Laboratory Condition. Int.J.Curr.Microbiol.App.Sci. 7(01): 2958-2969. doi: https://doi.org/10.20546/ijcmas.2018.701.354 